\title{
UDC 165.1943(324)
}

STARIKOVA Halyna - Candidate of Philosophy Sciences, Associate Professor, Associate Professor at the Philosophy Department, Kharkiv National University of Radio Electronics, 14, Nauky ave., Kharkiv, Ukraine, postal code61116(halyna.starikova@nure.ua)

ORCID: https: //orcid.org/0000-0002-3229-1442

DOI: https://doi.org/10.24919/2522-4700.43.16

To cite this article: Starikova, H. (2021). Novi pidkhody do pytannia pro typolohiiu neiavnykh znan [New approaches to the question of typologies of the tacit knowledge]. Liudynoznavchi studii: zbirnyk naukovykh prats Drohobytskoho derzhavnoho pedahohichnoho universytetu imeni Ivana Franka. Seriia "Filosofiia” - Human Studies. Series of "Philosophy": a collection of scientific articles of the Drohobych Ivan Franko State Pedagogical University, 43, 121-127, doi: https://doi.org/10.24919/2522-4700.43.16

\section{NEW APPROACHES TO THE QUESTION OF TYPOLOGIES OF THE TACIT KNOWLEDGE}

Summary. The article examines a special fragment of the human cognitive system-implicit knowledge. Modern philosophy does not pay enough attention to this impotent component of human cognition, especially the question of the typology of implicit knowledge. The purpose of the study: analysis of the development of implicit type of knowledge and formulation on this basis of approaches to the classification of implicit knowledge. Methodology. The work used general scientific and formal-logical methods of analysis, synthesis, comparison, abstraction. In addition, historical and genetic method were used, as well as linguistic, hermeneutic and heuristic research methods. Scientific novelty. A fundamentally new approach to the analysis of this type of human knowledge is introduced, as well as to the solution of the problem of developing a holistic typology of implicit knowledge relevant to modern theory of cognition. It is proposed to take as a basis for such a typology the historical-genetic approach, which consist in considering the main stage of formation of implicit knowledge in the history of homo sapiens, analysis of different types of implicit knowledge that arise at these stages, and implementation of the first steps to create a systematic typology of implicit knowledge. In the course of the analysis the special role played by the primitive types of implicit knowledge formed at ancient people at the biological level in the course of direct practical activity of people is provided. Autopoetic origins of primitive knowledge originate from the animal ancestors of human, but at a new level acquire new qualities. An important conclusion obtained in the article is the assumption, more precisely, the statement that this oldest layer of implicit knowledge retains its significance for modern human. Not only does this knowledge take part in many human cognitive actions, it is an integral part of the fundamental, basic layer of ascending prerequisite knowledge on which almost all human cognitive activity, including scientific, is based. A special kind of implicit knowledge is also analyzed - implicit knowledge, which is inherent in natural language. They also formed in ancient times, but not only exist but also actively operate within the modern natural languages of mankind. Implicit components of language play an important role both in the processes of direct communication and in theoretical and scientific cognition. Conclusions. Although the implicit, unconscious nature of this phenomenon makes it difficult to formalize, abstract-scientific and philosophical analysis, research in this area is necessary and impotent for a deeper and more accurate understanding of the specifics of human knowledge in general and abstract-logical, conceptual, scientific knowledge.

Key words: implicit knowledge, typology of implicit knowledge, autopoetics knowledge, cognitive system, natural language.

СТАРІКОВА Галина - кандидат філософських наук, дочент, дочент кафедри філософії, Харківський національний університет радіоелектроніки, 14, пр. Науки, Харків, Україна, індекс 61116 (halyna.starikova@nиге.иа)

ORCID: https: //orcid.org/0000-0002-3229-1442

DOI: https://doi.org/10.24919/2522-4700.43.16

Бібліографічний опис статті: Старікова, Г. (2021). Нові підходи до питання про типологію неявних знань. Людинознавчі студї: збірник наукових праџь Дрогобицького державного педагогічного університету імені Івана Франка. Серія «Філософія», 43, 121-127, doi: https://doi.org/10.24919/2522-4700.43.16 


\title{
НОВІ ПІДХОДИ ДО ПИТАННЯ ПРО ТИПОЛОГІЮ НЕЯВНИХ ЗНАНЬ
}

\begin{abstract}
Анотація. У статті досліджується особливий фрагмент когнітивної системи людини імпліщитні, або неявні, знання. Сучасна філософія не приділяе достатньої уваги иій важливій складовій частині людського пізнання, особливо питанню типології неявних знань. Мета дослідження: аналіз розвитку імпліцитного типу знань та формулювання на иій основі підходів до класифікації неявних знань. Методологія. У роботі використовувалися загальнонаукові та формально-логічні методи аналізу, синтезу, порівняння, абстрагування. Крім того, використано історичний та генетичний методи, а також лінгвістичний, герменевтичний і евристичний методи дослідження. Наукова новизна. Запроваджується принципово новий підхід до аналізу иьього типу людських знань, а також до вирішення актуальної для сучасної теорії пізнання проблеми розроблення цілісної типології неявних знань. Пропонується за основу такої типології узяти історико-генетичний підхід, який полягає у розгляді основних етапів формування неявних знань в історії розвитку hoто sapiens, аналізі різних типів імплічитних знань, що виникають на изи етапах, $i$ здійснення на иій основі перших кроків зі створення системної типологізаиії неявних знань. У проиесі аналізу доведена особлива роль, яку відіграють первісні типи імплічитних знань, щзо формуються у прадавніх людей на біологічному рівні у процесі безпосередньої практичної діяльності людей. Аутопоетичні витоки первісних знань беруть свій початок від тваринних предків людини, але на новому рівні отримують нові якості. Важливим висновком, який отримано у статті, є припущення, точніше, твердження, щяо ией найдавніший шар імпліщитних знань зберігає своє значення і для сучасної людини. Ці знання не тільки беруть участь у багатьох пізнавальних діях людини, вони є невід'ємною складовою частиною фундаментального, базового шару висхідних передумовних знань, на яких базується майже уся пізнавальна діяльність людини, у тому числі й наукова. Проаналізовано також особливий різновид неявних знань - імпліцитні знання, які притаманні природній мові. Вони також формуються у прадавні часи, але не тільки існують, але й активно діють у межсах сучасних природних мов людства. Імпліцитні компоненти мови відіграють важливу роль як у процесах безпосередньої комунікації, так $і$ у теоретичному, науковому пізнанні. Висновки. Хоча імплічитність, неусвідомлений характер иього феномену робить його важккодоступним для формалізованого, абстрактно-наукового та філософського аналізу, дослідження у иьому напрямі є необхідними і важливими для більи глибокого і точного розуміння спечифікияклюдського пізнання взагалі, такі абстрактно-логічного, понятійного, наукового пізнання. Імпліщитна складова частина пізнання присутня у всіх без винятку видах людської діяльності - як в інтуїтивних діях «на рівні живої істоти», так і у специфрічно людській діяльності - пізнавальній, практичній, творчій. Тому дослідження проблеми імпліцитного знання залишається актуальним для сучасної теорії пізнання та епістемологіï.
\end{abstract}

Ключові слова: неявне знання, імплічитне знання, типологізація імпліцитних знань, аутопоез, когнітивна система, природна мова.

Urgency of the problem. The problem of implicit components of cognition has interested philosophers since ancient times, but for a long time it was on the periphery of philosophical research. Only in the middle of the twentieth century, due to the development of post-positivism and discussions around this concept, special attention of researchers was attracted by the phenomenon of unconscious components of human knowledge, including scientific. With regard to scientific knowledge, this phenomenon is called "implicit knowledge". Although the implicitness, unconscious nature of this phenomenon makes it difficult to access for formalized, scientific and philosophical analysis, research in this direction is necessary for a deeper and more accurate understanding of the specifics of both human cognitions in general and the features of abstract logical, conceptual, scientific cognition. It should be emphasized that the implicit component is present in all types of human activity without exception, both in intuitive actions at the level of a "biological being" and in specifically human activity - cognitive, practical, and creative. Therefore, the study of the problem of implicit knowledge is relevant for the modern theory of knowledge and epistemology.

Analysis of recent research and publications. It can be considered that the modern stage of studying the implicit components of the human cognitive system originates in the work of M. Polanyi "Personal knowledge" (Polanyi, 1958), in which the initial definition of the term " tacit knowledge" is given. The followers of Polanyi have largely focused their attention on the sociocultural and socio-practical nature of tacit knowledge. This aspect of the functioning of the cognitive system was considered in one way or another in the works of M. Malkay, J. Hilbert, T. Kuhn. In the future, the one-sidedness and limitations of this approach are gradually overcome in the works of V. Lektorsky, L. Mikeshina, V. Geroimenko, K. Peipert, however, the question of developing a typology of tacit knowledge was not raised in these works.

To date, there are various variants of the typology of tacit knowledge, however, as a rule, there is 
no single criterion for classification in them, science and philosophy have not yet developed a single principle for such a typology. So, in some studies, the following typology of implicit knowledge is proposed (Губанова, 2010):

1. Implicit knowledge. This knowledge is the result of practical actions of the individual, it is not realized and is formed in his "personal unconscious". Karpov believes that the manifestations of implicit knowledge can be seen, for example, in the acquired skills of managing complex multi-parameter systems, that it is felt by a person as an intuitive activity.

2. Intuitive knowledge. In contrast to implicit knowledge, intuitive knowledge exists at the levels of "personal and collective unconscious". For example, this is an understanding and feeling of a situation through the grasping of it by relict forms of the "collective unconscious," through archetypes.

3. Relic knowledge. It is the content of the inherited forms of the "collective unconscious", that is, archetypes and instincts. In humans, this knowledge manifests itself in intuitive actions in extreme situations, in a system of uncontrolled attitudes towards a child in a family, in a social group. Relic knowledge is the same for all individuals of the same biological species (including humans).

4. Integrated knowledge. It is a synthesis of rational, intuitive and relict knowledge. Professional activities of various kinds require knowledge of different depths.

5. "Background knowledge", which characterizes a certain type of implicit knowledge, as opposed to verbalized knowledge. Background knowledge is the mutual knowledge of the realities of the speaker and the listener, which is the basis of language communication. Background knowledge forms part of what sociologists call mass culture, is information that is certainly known to all members of the community.

We find another version of this typology in the works of V. Tsvetkov (Цветков, 2015). He offers several options for the classification of tacit knowledge, and each option has its own, different from the others, criteria for classification. Thus, he distinguishes subjective and non-subjective implicit knowledge according to the criterion of connection with the subject-bearer of knowledge. Subspecies here are codified and uncodified, as well as articulated and non-articulated implicit knowledge, that is, the author applies a simplified approach, relying solely on binary, mutually exclusive characteristics. Further, he subdivides subjective implicit knowledge into the following subspecies: worldview; paralinguistic; empirical; implicit, which includes unconscious types of background knowledge; codified by subject code; specialized.

Defining the purpose and main objectives of study. We see that the proposed approach overlaps in some way, in some way duplicates the previous version, but both of them, like other variants existing in modern epistemology, are characterized by incompleteness and vagueness of the typologization criteria. A generalized approach is also possible, which distinguishes different types according to their role in the cognitive process and content. These types include prerequisite (substantiated), practical-activity and value-evaluative implicit knowledge. The prerequisite includes implicit knowledge, which is the basic, initial basis and, at the same time, a condition for the implementation of cognitive activity. According to modern research, such knowledge includes two main components: 1) fundamental ideas that are not realized; 2) stable cognitive structures underlying cognition, but also not realized by the subject of cognition. The practical-activity type includes those implicit knowledge that are formed by imitation in the process of joint activities of people and in the cognitive process perform exclusively an instrumental-auxiliary function. In recent decades, researchers have paid special attention to the value-evaluative type of implicit knowledge and their special role in cognition, in particular, their influence on the implementation of scientific cognition (Микешина, 2007).

Summarizing what has been said, it can be noted that implicit knowledge is not homogeneous. It differs in a different structure, content, specifics of functioning, role and place in the general cognitive process. On the other hand, it is still difficult to draw clear boundaries between different types of tacit knowledge, which significantly complicates the development of a clear typology of this type of knowledge. In addition, the concepts of tacit knowledge available to date almost completely ignore the question of its genesis. This does not mean the formation of a specific kind of implicit knowledge, for example, an unconscious skill, etc. This is an evolutionary-historical approach to this issue. This aspect of tacit knowledge has not yet become a subject of study, although we believe that such an approach will allow us to take a fresh look at the specifics of tacit knowledge in general and at the question of their typology, in particular.

Basing on the analysis performed, we propose the following formulation of the research objectives. First, to formulate general principles for studying the genesis of implicit knowledge. Further, relying on the obtained periodization of the emergence and development of implicit knowledge, propose an appropriate version of the typology of this type of knowledge.

The main research material. It should be noted that both the presented and other similar typologies are characterized by incompleteness and an excessive, unreasonable variety of grounds for classification, 
which significantly complicates the creation of a single integral system of ideas about the types of implicit knowledge. We believe that one of the main reasons for such limited approaches is the fact that all researchers consider the tacit knowledge of modern man as an established, specifically human phenomenon, ignoring the question of the historical genesis of such knowledge and their closest connections with the cognitive structures of human biological predecessors. Based on this, we consider it promising to consider the issue of the typology of tacit knowledge by analyzing the formation and development of this type of knowledge in the history of the formation of mankind. We propose to carry out the typologization of tacit knowledge according to the most general and obvious criterion - the stages of its formation, from the most ancient, reflex-physiological in nature and archetypal in the carriers of tacit knowledge to modern ones related to scientific and technological human activity.

The most ancient can be considered the so-called "proto-knowledge" - information about the surrounding world, which is inherited from animal ancestors. Despite the absence of the possibility (for the bearer of this information) of its verbalization and awareness, in our opinion, it must also be attributed to implicit knowledge, since such knowledge is extremely necessary for the survival of both the individual and the genus as a whole. This "knowledge" was used by the ancestors of Homo sapiens and the first representatives of our kind long before the appearance of homo sapiens proper. These include innate instincts and unconditioned reflexes, as well as mechanisms for the formation of conditioned reflexes, which become the initial basis for moving a person to the next level of creation and preservation of knowledge.

This is the knowledge obtained in the process of autopoiesis, direct practical interaction of a person with the environment. This kind of knowledge, in principle, is received by all living beings on our planet, since they all interact with the environment, thus receiving certain information that they "take into account" in their actions. At the level of higher mammals, and later of humans, this information can be recorded in the form of images that are retained for some time in the memory, and not in the depths of the unconscious. By their origin, from the very beginning, they have a personal, individual character, since they are received by a specific person in his own practical activity. However, due to the fact that speech and language have not yet been formed, this information is quite difficult, on the one hand, to convey to other people, but it is not easy to remember yourself. Some kind of "carriers" are needed to store such information - they can be images or perceptual impressions of different types. For example, a smell (sound, color, etc.) evokes the memory of a certain situation and the corresponding correct, effective actions in this case.

As we have already noted, this type of tacit knowledge can be considered rather biological, psychophysiological, inherent in higher primates rather than in humans. However, this information is gradually recorded by the surrounding people and, if it is useful / important for the processes of survival and adaptation, it can become "common" - this is how such tacit knowledge can be transferred to other members of the human community at a practical, autopoietic level. We believe that the described type of implicit knowledge can be considered as the initial one for all subsequent types of human implicit knowledge. In addition, the principle itself, the mechanism of autopoietic formation of such knowledge remained with modern mankind, it is still implemented in the process of human activity and its results are still not recognized, although they no longer concern survival in the natural environment, but, for example, serious and complex scientific experiments. It is this kind of knowledge that has received the name "implicit" in the work of M. Polani.

For tens of thousands of years, such a process of obtaining, preserving and transferring knowledge has become hereditary and innate for mankind, it is inherent in all representatives of homo sapiens. It is obvious from the analysis that the "carriers" of this process, as in ancient times, are rather simple psychophysiological structures. It can be assumed that some important information is recorded by the senses, but does not enter consciousness for analysis. This is probably due precisely to the history of the formation of this cognitive mechanism. In the process of evolution, it functioned quite successfully without the participation of consciousness, so all information remained and was processed at the level of the subcortex; its awareness, verbalization and formalization are still associated with significant difficulties.

As an example, let's consider the famous case of a scientist from Stanford University. He developed a new installation and published a detailed description of the technological process in a scientific journal. Researchers from different countries tried to reproduce this development, guided by the text of the article, but no one succeeded. Then all interested scientists came to the author, and he showed them the structure itself and its functioning. He did not provide any new information. When the scientists returned to their laboratories, all the researchers had their equipment working. Scientists came to the conclusion that during direct communication and interaction with the author, some additional essential information appeared, which, nevertheless, was not realized and verbalized either by the author of the work or his colleagues. However, this information turned out to be decisive in the implementation 
of the experiment. What was the content of this information, no one ever found out.

This can be considered as a classic example of an autopoietic method of obtaining implicit knowledge, the content of which is already specifically human, moreover, scientific, but at the same time remains unconscious. We can say that in the process of human development and the formation of civilization, the biological content of this type of knowledge is gradually replaced by the sociocultural one. It should be noted that a similar evolution - from biological content to specifically human - is observed in another, previously mentioned type of tacit knowledge - premise knowledge.

On the other hand, the emergence of this form of tacit knowledge testifies to the formation of specifically human methods of fixing, storing and transmitting information. This type can be considered a "protosocial" information construct, which actively participates in the transformation of the environment carried out by a person in the process of autopoietic interaction with the world, in accordance with the interests and goals of the human community. During this process, both the improvement of the forms and methods of practical activity, and the emergence of new knowledge about the world, take place, however, implicit knowledge, as before, retains an important role in human life.

With the advent of speech, carriers of information change radically, fundamentally, including, paradoxically, and implicit knowledge. More precisely, the range of such knowledge and the scope of their application are expanding. There is a final "shift" towards the social form of fixing and transmitting information. From now on, the word becomes the main carrier of information. Therefore, at this stage, a new layer of tacit knowledge is being formed, which are closely related to natural language. This aspect of tacit knowledge is studied mainly by linguists, and the emphasis is on the applied aspects of this phenomenon - the problem of translation into foreign languages or teaching foreign languages. It is interesting to note that one of the founders of European linguistics, W. von Humboldt, drew attention to this special implicit side of language at the end of the 19th century. He emphasized the presence of the reverse influence of the language on the national spirit and the intellectual level of the people, emphasizing that such an action is immanent and constructive for the language (Wilhelm von Humboldt, 1997 , p. 58). We meet similar reasoning in the works of M. Foucault: "The grammatical structures of language turn out to be a priori prerequisites for everything that can be expressed with the help of speech" (Foucault, 1982, p. 321).

There is a deep layer in the language of every nation, from which natural language "grows" and is based.
This layer includes implicit components, unconscious structural and semantic premises of the language. Therefore, in particular, science can be considered as a text in a natural language, where the image (and its semantic meaning) are fundamental, decisive for the development of a picture of the world and the construction of theories, that is, for the embodiment of our idea of the real world, a representation that is refracted through our language, traditions, etc. (Голубовська, 2004).

Within this approach, natural language is a metaprogram that regulates through various kinds of prescriptions - commandments, aphorisms, proverbs, advertising, PR - certain forms of human behavior (Маслова, 2014, p. 45). It is especially important for us that these prescriptions are far from always being "open", conscious and meaningful information for the subject-individual. Very often, especially at the level of commandments and traditions, their real meaning, the real objective reason for their formation has long been forgotten, and the model of behavior becomes sacred without understanding its essence. Thus, such information also exists in the human community in the form of tacit knowledge. An example would be various (depending on geographic and climatic conditions) food restrictions or hygiene rules; clothing standards in various religions are usually of this nature. We see that in these cases, behind the explicit sign, which is "understood" by the society, there is actually unconscious, implicit, forgotten information many generations ago. It is also one of the types of implicit constituents of the language.

Such components include a number of non-verbal linguistic, linguo-cultural codes, which are more figurative than linguistic in nature. These are different figurative systems of a certain culture that perform allegorical and symbolic functions. These systems differ in that outwardly they have a linguistic form, but their semantics do not coincide with this form. For example, the kinesthetic code, which was formed on the basis of the non-verbal code of facial expressions and gestures, on the one hand, contains images of these gestures in its internal form, on the other hand, the meaning of these images does not correspond to their verbal design (Маслова, 2014, p. 48).

Quite understandable from this point of view is the fact that different types of codes are preferred in different cultures. So, for the inhabitants of Great Britain, the sports code is of particular importance, for the Slavic peoples - the somatic one. All of the above emphasizes the implicit specificity of this fragment of the language, which in theoretical linguistics is called "non-equivalent vocabulary."

As an implicit component of the language, researchers also single out the so-called "background" or "extralinguistic" knowledge. In the process 
of communication in natural language, the speaker and the listener must, in addition to the language itself, also possess a significant amount of background knowledge - knowledge about realities that are not spoken out, but are implied in each specific situation. Back in the late 80 s of the twentieth century, linguists came to the conclusion that it is necessary to display and take into account this implicit knowledge in the theoretical model of the language. "... it is impossible to understand the language if you do not have an idea of the conditions in which the people who speak this language live," wrote A. Meye (Meillet, 1966, p. 8). However, the desire to study background knowledge and other unconscious components of speech, relying solely on rational-analytical ideas about the possibility of full, comprehensive awareness of the content of the language, did not bring the desired results, since it was found that most extralinguistic phenomena are unconscious, implicit and not verbalized. Linguists found that such studies did not take into account the presence of at least two levels of language being: speech (verbal-conceptual) and non-verbal, implicit (semantic). In recent years, cognitive psychology and psycholinguistics have been actively working on solving these problems. Background implicit knowledge, in particular, belongs to the second, non-verbal, semantic level, as well as linguo-cultural codes or non-equivalent vocabulary.

Conclusions. In this work, a new approach to solving the problem of typologization of implicit knowledge was proposed. This approach is based on the analysis of the origin and development of implicit knowledge in the history of mankind. This analysis showed that the mechanism for the formation of tacit knowledge is not specifically human, it is inherited from the distant biological ancestors of man and has been improved in the course of the historical development of mankind. The genetic criterion made it possible to isolate the most ancient and "primitive" types of tacit knowledge, which until now have not been the subject of research within the framework of epistemology or theory of science cognition. However, as our work has shown, this type of knowledge plays an essential role in the cognitive process of a modern civilized person. In addition, this ancient layer of tacit knowledge is closely related to the knowledge acquired by man, including the modern one, in the process of autopoiesis - joint activity with other people aimed at both cognition of the surrounding reality and its transformation. The knowledge obtained in this way most often remains unconscious, and it was they that became the object of research in the work of the classic of this problem, M. Polani.

In addition, another very important, but still not studied at the theoretical level, implicit component of the human cognitive system requires serious attention - implicit knowledge present in natural language. This component of tacit knowledge is an integral part of cognitive activity, constantly exerts a significant influence on all cognitive processes, even special scientific ones, but the study of this influence has not yet become the subject of philosophical research.

In general, the need for further specific scientific and philosophical-theoretical study of the problem of tacit knowledge using the historical-genetic approach to develop a single holistic typology of tacit knowledge is obvious.

\section{BIBLIOGRAPHY}

1. Polanyi, M. Personal Knowledge: Towards a Post-Critical Philosophy. University of Chicago Press. 1958.

2. Губанова Е.О. Неявное знание: сущность и виды. URL: http://www.zpu-journal.ru/zpu/contents/2010/4/

3. Цветков В.Я. Паралингвистические информационные единицы в образовании. URL: https://pnojournal. wordpress.com/2015/06/15/.

4. Микешина, Л.А. Эпистемология ценностей. М.: (РОССПЭН), 2007. 439 с.

5. Wilhelm von Humboldt. Essays on Language. T. Harden and D. Farelly (eds.), Frankfurt, Berlin, Bern, New York: P. Lang. 1997.

6. Foucault, Michel. The Subject and Power. University of Chicago Press, 1982.

7. Голубовська, І.О. Етнічні особливості мовних картин світу: монографія. Київ: Логос, 2004. 283 с.

8. Маслова, В.А. Современная лингвистика и исследования ментальности в XXI веке: монография. Киев: Логос, 2014. C. 44-52.

9. Meillet, A. The comparative method in historical linguistic. Translated by Gordon B. Ford. Presses Universitaires de France, Jr., 1966.

\section{REFERENCES}

1. Polanyi, M. (Ed.). (1958). Personal Knowledge: Towards a Post-Critical Philosophy. University of Chicago Press.

2. Gubanova, E.O. Neyavnoe znanie: suschnost i vidyi [Tacit knowledge: essence and kinds]. Retrieved January 25, 2021, from http://www.zpu-journal.ru/zpu/contents/2010/4/ [in Russian].

3. Zvetkov V.Ya. Paralingvisticheskie informatsionnyie edinitsyi $\mathrm{v}$ obrazovanii [Paralinguistic information units in education]. Retrieved February 7, 2021, from https://pnojournal.wordpress.com/2015/06/15/ [in Russian].

4. Mikeshina, L.A. (Ed.). (2007). Epistemologiya tsennostey [Epistemology of Values]. Moscow: ROSSPEN. [in Russian].

5. Wilhelm von Humboldt. (Ed.). (1997). Essays on Language. T. Harden and D. Farelly (eds), Frankfurt, Berlin, Bern, New York: P. Lang. 
6. Foucault, Michel. (Ed.). (1982). The Subject and Power. University of Chicago Press.

7. Golubovska, I.O. (Ed.). (2004). Etnichni osoblivosti movnyh kartyn svitu [Ethnic Features of the Language Pictures of the World]. Kyiv: Logos [in Ukrainian].

8. Maslova, V.A. (Ed.). (2014). Lingvokulturniy kod kak sposob opisaniya yasyka [Linguacultural Code as a Way to describe a Language]. Kyiv: Nauk. Dumka [in Ukrainian].

9. Meillet, A. (Ed.). (1966). The comparative method in historical linguistic. Translated by Gordon B. Ford. Presses Universitaires de France, Jr. 